\title{
Key Performance Indicators in Corporate Finance
}

\author{
Strelnik E. U. ${ }^{1}$, Usanova D. S. ${ }^{1} \&$ Khairullin I. G. ${ }^{1}$ \\ ${ }^{1}$ Kazan Federal University, Institute of Management, Economics and Finance, Kazan, 420008, Russia \\ Correspondence: Strelnik E. U., Kazan Federal University, Institute of Management, Economics and Finance, \\ Kazan, 420008, Russia. Tel: 7-927-243-0497. E-mail: jstr06@mail.ru
}

\author{
Received: March 19, 2015 Accepted: March 31, 2015 Online Published: April 30, 2015 \\ doi:10.5539/ass.v11n11p369 URL: http://dx.doi.org/10.5539/ass.v11n11p369
}

\begin{abstract}
The relevance of the study caused by the necessity to assess the impact of KPI system for growth of shareholders welfare and the satisfaction of the interests of other stakeholders. KPI concept suggests widespread use of these factors as measures of internal and external efficiency, as well as an incentive for management to meet the strategic objectives of the company. The article examines the influence of key performance indicators on the value of Russian companies. We used the following tools of econometric research: content analysis and econometric modeling to conduct the study.
\end{abstract}

Keywords: KPI, Performance management, GRI, corporate finance, sustainability report

\section{Introduction}

In recent years, scientific publications often criticized management models based on the traditional financial performance indicators, as they do not allow a complete performance of the company's activities. Modern advanced tools of performance management: benchmarking, lean production, Management by Objectives (MBO) concept of Peter Drucker, the system (table) performance of the French scientist JL Malo (Tableau de bord), Total Performance Scorecard of Hubert Rampersad, Total Quality Management (TQM), Balanced Scorecard of Norton and Kaplan, and others are increasingly replacing traditional management systems.

One of the most recognized and a sought-after instrument of performance management is a system of key performance indicators (KPI).

Some authors consider a system of key performance indicators as a system of financial and non-financial indicators characterizing the state and prospects of company development, which allows orient the departments and employees to achieve tactical and strategic objectives of the company. For others authors, KPI - are indicators of the compliance level with the current performance of the strategic goals of the company. KPI system should translate the company's strategy on the language of measurable economic indicators and ensure its implementation. Thus, most of the authors interpret KPI as indicators, which are used to assess the degree of achievement of strategic and tactical objectives of a company. KPI system is also used in HR management.

KPI system provides managers with a universal tool that interprets the vision and strategy of the company through a set of inter-related indicators. Scope of KPI system is quite extensive and plays an essential role in the strategic management of finances and in the process of value creating. In general, all of the researches and scopes of application of key performance indicators can be divided into three groups: 1) the success of the company (the achievement of strategic and tactical objectives); 2) management of the organization (the process of transforming strategic objectives at the operational level); 3) human resource management and motivation (performance of employees).

\section{KPI Characteristic}

Effective KPI system assumes that each component meets certain criteria. Basically, there are the following characteristics of "effective" key performance indicators: address affiliation, strategic affiliation, achievability, boundedness, equilibrium and interconnectedness, standardizing, relevance, rationality.

Address affiliation means that each key performance indicator is assigned to a specific individual or group of business areas responsible for relevant results (i.e., is in his area of responsibility).

Key performance indicators are always linked to corporate strategic objectives, key business processes and development projects, resulting in a strategic affiliation. 
Approved indicators and standards should be achievable.

In their work many authors suggest, that the number of objectives should be no more than five, the number of key performance indicators for each division $5-8$. This will allow managers and the company's management to focus on the most important issues.

Equilibrium and interconnectedness means that the KPI should be balanced and interconnected with each other.

Key performance indicators are based on standard definitions, rules and calculations that can be integrated across the company. Each figure should carry meaning and be the basis for the analysis. In addition, KPI should be supported by appropriate individual incentives and contribute to staff motivation.

\section{Features of the Application of Financial and Non-Financial KPI in Corporate Governance}

The uncertainty in the economic environment and the impact of external factors require constant change of key performance indicators to assess the performance of management and shareholders. Companies have to adapt to the continuously changing conditions: revise rates and implement non-financial indicators in the area of corporate social responsibility. Management's ability to develop a strategy for sustainable development based on financial KPI is a significant factor in the creation of shareholder value. Equally important is the ability of management to implement the strategy, recognize and manage the financial risk.

The financial statements provide only historical data, while investors need a comprehensive analysis of the business and its potential growth opportunities. For this purpose, non-financial reporting is used. In its' scope of application contained the most important key performance indicators in the long run on three main aspects of the company: social, economic and environmental.

The majority of Russian and international companies publish non-financial reporting in accordance with GRI. Using a non-financial reporting on the GRI as an information base for the calculation gives the opportunity to make a system of key performance indicators clear and transparent, not only for internal users, but also to external. While non-financial reporting is voluntary, companies are facing with increasing pressure from NGOs, customers, suppliers and employees in order to obtain more information about the long-term impact on a society. In particular, the major customers can force companies to become more transparent. A well-designed reporting on sustainable development helps companies to create a positive business reputation, increase transparency and strengthen the confidence of stakeholders.

Motivations for corporations to publish non-financial reporting in accordance the GRI can be different, that is shown in Figure 1.

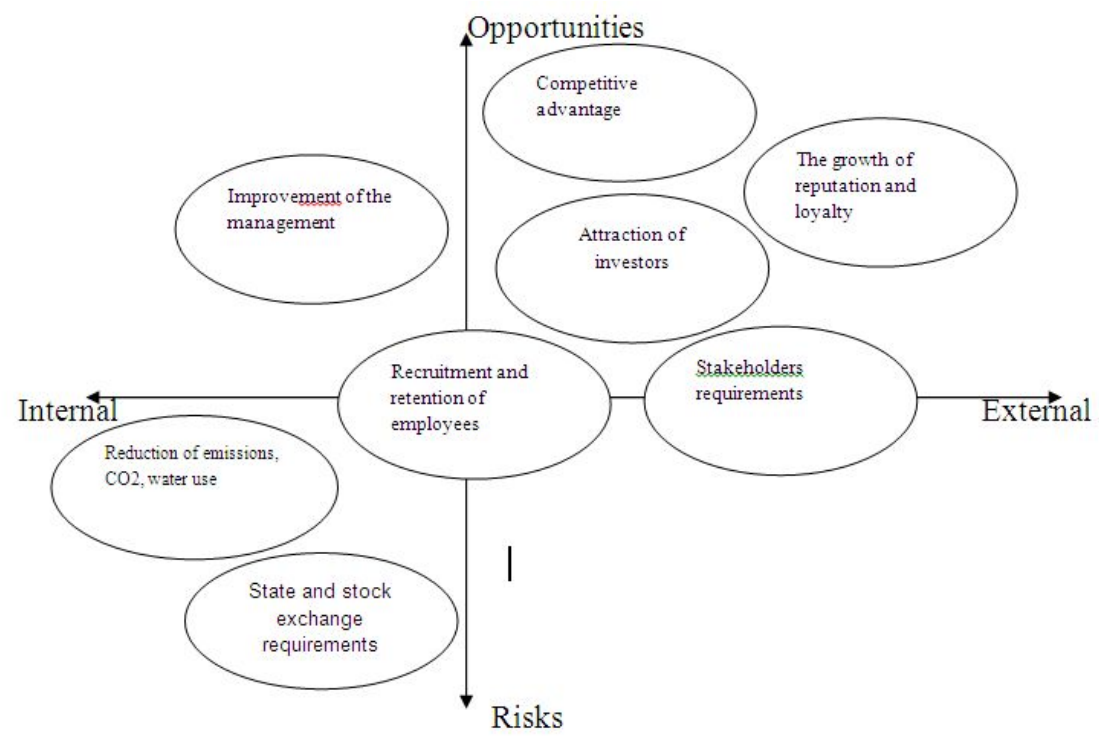

Figure 1. The main motives for publishing GRI sustainability reports

Potential investors are increasingly using non-financial statements of the company for making investment decisions, assessment of goodwill and risk. And every year the role of non-financial KPI is increasing, and with it, the role of non-financial reporting in corporate governance increasing too. These facts confirm the relevance of empirical research on the association of KPI system with the value of business. 
According to the official web site of the Global Reporting today there are 14,366 non-financial reports under GRI of 6040 international companies, published since 1999. The number of non-financial reports published under the GRI from different countries is growing every year.

Today in Russia, many large public companies, and non-profit organizations (mainly charity) publish GRI sustainability reports. The Library of non-financial reports of the Russian Union of Industrialists and Entrepreneurs has 134 registered reports, issued since 2000. All this, as well as the growing demand for GRI sustainability reports in Russia - would make the choice of having GRI standard as the main feature for the construction of the sample for the study.

\section{Database}

The final sample of this study included 32 Russian companies that publish GRI sustainability reports in following economic activities: production of crude oil and natural gas; the provision of services in these areas ( 8 companies), production and distribution of electricity, gas and water (14 companies), metallurgical production and fabricated metal products (6 companies), the production of coke and petroleum products ( 2 companies), Communications ( 3 companies).

\section{Method}

The basis of our study is the hypothesis of a relationship between the quality of KPI system and cost characteristics of the company, namely: it is assumed that the quality of financial and non-financial key performance indicators made and disclosed using the GRI, has a positive effect on a company's value.

Most commonly used in practice indicators we've chosen as dependent variables: market capitalization (Y1.1. MK), standardized EVA (Y1.2. - sEVA) and market to book (Y1.3. - MtB), as independent variables - the quality of KPI, expressed by seven indicators: quality of GRI sustainability reports (X1), the presence of the audit of GRI sustainability report (X2), the amount of KPI, disclosed by a GRI sustainability report (X3), the presence of feedback in the questionnaire in a GRI sustainability report ( X4), the frequency of publication the GRI sustainability report (X5), the length of the of GRI sustainability report in pages (X6); availability of public endorsement/approval (X7).

Independent variables $(\mathrm{X} 1, \mathrm{X} 2, \mathrm{X} 3, \mathrm{X} 4, \mathrm{X} 5, \mathrm{X} 6, \mathrm{X} 7)$ calculated using content analysis conducted using software (MyWordCount). For example, "the level of quality of GRI sustainability reports" is calculated in points according to the ABC-scale. Moreover, this level under ABC-scale is assigned to either the company itself or by an independent auditor.

\section{Results}

With all performed iterations were chosen independent variables to test hypothesis by the sample of Russian companies: financial independence ratio (X1), financial leverage (X2), the size of the company (ext. Logarithm of assets) (X3), return on equity (ROE ) (X4), return on sales (ROS) (X5) and earnings per share (EPS) (X6). As a dependent variable was taken as the logarithm of the market value added (Y2 - MVA), so this figure is one of the most common indicators to assess the market value of companies in the modern theory and practice of corporate finance, and administrative expenses (Y3-AC).

In order to test the hypothesis we've made up a linear multiple regression equation. Table 1 shows equations in a standardized form. This form of the equation allows comparing the degree of influence of the independent variables on the dependent variable.

Table 1. A standardized form of the obtained regression equations

\begin{tabular}{lr}
\hline Dependent variable & \multicolumn{1}{c}{ Standardized equation } \\
\hline Y1.1. - MK & $0,179 * \mathrm{X} 1+0,026 * \mathrm{X} 2-0,046 * \mathrm{X} 3-0,039 * \mathrm{X} 4-0,121 * \mathrm{X} 5+0,107 * \mathrm{X} 6+0,14 * \mathrm{X} 7-0,116 * \mathrm{~K} 1$ \\
& $+0,422 * \mathrm{~K} 2+0,225 * \mathrm{~K} 3+0,023 * \mathrm{~K} 4-0,022 * \mathrm{~K} 5$ \\
Y1.2. - sEVA & $-0,058 * \mathrm{X} 1+0,006 * \mathrm{X} 2+0,081 * \mathrm{X} 3-0,096 * \mathrm{X} 4+0,045 * \mathrm{X} 5-0,032 * \mathrm{X} 6$ \\
& $-0,023 * \mathrm{X} 7-0,053 * \mathrm{~K} 1-0,058 * \mathrm{~K} 2+0,921 * \mathrm{~K} 3+0,056 * \mathrm{~K} 4+0,056 * \mathrm{~K} 5$ \\
Y1.3. - MtB & $-0,213 * \mathrm{X} 1+0,121 * \mathrm{X} 2+0,079 * \mathrm{X} 3+0,217 * \mathrm{X} 4-0,014 * \mathrm{X} 5-0,062 * \mathrm{X} 6+0,056 * \mathrm{X} 7-0,357 * \mathrm{~K} 1+$ \\
& $0,027 * \mathrm{~K} 2+0,538 * \mathrm{~K} 3-0,107 * \mathrm{~K} 4+0,227 * \mathrm{~K} 5$ \\
Y2 - MVA & $-0,107 * \mathrm{X} 1-0,197 * \mathrm{X} 2+0,506 * \mathrm{X} 3+0,246 * \mathrm{X} 4-0,018 * \mathrm{X} 5+0,196 * \mathrm{X} 6$ \\
$\mathrm{Y} 3-\mathrm{AC}$ & $-0,217 * \mathrm{X} 1-0,029 * \mathrm{X} 2+0,227 * \mathrm{X} 3-0,073 * \mathrm{X} 4-0,037 * \mathrm{X} 5+0,079 * \mathrm{X} 6$ \\
\hline
\end{tabular}


The Table 1 shows that the greatest impact on the quality of the KPI system has the second of the dependent variables - a standardized economic value added. This is evidenced by a high R-square value of 0.903: this means that the independent variables explain $90.3 \%$ of the independent variable (standardized EVA) change. At the same time the independent variables explain the changes in the market capitalization of $48.5 \%$, and the market to book - by $37.3 \%$, Lg MVA - 45.4\%, administrative expenses - 10, 8\%. The results of tests are presented in Table 2 .

Table 2. The significativity of regression equations

\begin{tabular}{llllll}
\hline & Y1.1. (MK) & Y1.2. (sEVA) & Y1.3. (MtB) & Y2 (Lg MVA) & Y3 (AC) \\
\hline Multiply R & 0,696 & 0,950 & 0,611 & 0,674 & 0,329 \\
R-square & 0,485 & 0,903 & 0,373 & 0,454 & 0,108 \\
Standardized R- square & 0,433 & 0,893 & 0,310 & 0,428 & 0,066 \\
Fob & 9,407 & 92,576 & 5,947 & 17,480 & 2,546 \\
Fcr (a=0,05) & 1,750 & 1,750 & 1,750 & 1,750 & 1,750 \\
Significativity of regression & significant & significant & significant & significant & not significant \\
\hline
\end{tabular}

The regression models discussed above do not contain autocorrelation, multicollinearity and heteroscedasticity. Therefore, we confirmed our hypothesis.

\section{Conclusion}

As a result of research, we came to the following conclusions: 1) The key performance indicators system has a positive impact on the company's value; 2) On the market value of the company most strongly influence performance indicators such as the size of the company and the return on equity.

Among the most important practical guidance in the use of KPI system in modern corporations are the following. First, the requirement for large companies to publish GRI sustainability reports at the legislative level. Secondly, it's needed to develop a policy of feedback from stakeholders in the field of key performance indicators in order to inform about the essential facts of the company's activity, as well as to get feedback and understanding immediately after the publication of the annual GRI sustainability report. Third, the present study illustrated the importance of tying the system of key performance indicators for management costs, so Russian companies should follow this fundamental principle of the KPI system.

\section{References}

Bagautdinova, N. G., Malakhov, V. P., \& Kundakchyan, R. M. (2013). Development of management system of manufacturing companies on the basis of management accounting elements. World Applied Sciences Journal, 27(13), 53-57.

Bagautdinova, N. G., Novenkova, A. Z., \& Sarkin, A. V. (2013). Quality management system formulation and implementation as a factor of enhancement of the university role in the local development. World Applied Sciences Journal, 27(13), 38-42.

Carlucci, D., \& Schiuma, G. (2010). Determining Key Performance Indicators: An Analytical Network Approach. Handbook on business information systems. World Scientific. http://dx.doi.org/10.1142/978981283 6069_0021

Coskun, A. (2006). Using the Balanced Scorecard in Strategic Performance Management: A Survey on Turkish Manufacturing Companies. Muhasebe Bilim Dünyasi Dergisi, 8(1), 127-153

Demydyuk, G. (2012). Optimal Financial Key Performance Indicators: Evidence from the Airline Industry. Accounting \& Taxation, 3(2), 39-51.

Guthrie, J., Dumay, J., \& Farneti, F. (2010). GRI Sustainability Reporting Guidelines for Public and Third Sector Organizations. Public Management Review, 12(4).

Huselid, M. A. (1995). The Impact of Human Resource Management Practices on Turnover, Productivity, and Corporate Financial Performance. Academy of Management Journal, 38(3), 635-672. http://dx.doi.org/10.2307/256741

Kaplan, S. R., \& Norton, P. D. (1992). The Balanced Scorecard: measures that drive performance. Harvard Business Review, January - February, 71-79.

Kaplan, S. R., \& Norton, P. D. (1996) Linking the Balanced Scorecard to strategy. California Management Review, Fall, 53-79. http://dx.doi.org/10.2307/41165876 
Morard, B., Stancu, A., \& Jeannette, C. (2013). Time Evolution Analysis and Forecast of Key Performance Indicators in a Balanced Scorecard. Global Journal of Business Research, 7(2), 9-27.

Reineck, M., Poltermann, J., May, M., \& Pelzeter, A. (2011). Measuring Corporate Sustainable Development in Facilities Management with Key Performance Indicators. OIDA International Journal of Sustainable Development, 2(10), 69-76.

Safiullin, L. N., Ismagilova, G. N., Safiullin, N. Z., \& Bagautdinova, N. G. (2012). The development of welfare theory in conditions of changes in the quality of goods and services. World Applied Sciences Journal, 18(Special Issue of Economics), 144-149.

Safiullin, M. R., Samigullin, I. G., \& Safiullin, L. N. (2013). Model of Management of Competitiveness of a Machine-building Complex. World Applied Sciences Journal, 27(13), 212-216.

\section{Copyrights}

Copyright for this article is retained by the author(s), with first publication rights granted to the journal.

This is an open-access article distributed under the terms and conditions of the Creative Commons Attribution license (http://creativecommons.org/licenses/by/3.0/ 